\title{
The Social Impact of Immigration in Italy, a Composed Index
}

\author{
Luca Rossi, Ing. PhD \\ Professor of Statistics \\ Università degli Studi Niccolò Cusano \\ Telematica Roma \\ Via Don Carlo Gnocchi, 300166 Roma
}

\begin{abstract}
This study analyses the social impact of immigration, focusing on elements that allow to determine the effects of their presence in Italy. The analysis has therefore focused on three areas (the labour market, the economy and social life).and through a composed index (immigrants' situation), show how these contribute to define immigrants' situation. The analyses: i) confirms the increase of the phenomenon of immigration in Italy; ii) identifies the main areas related to social impact of immigration; iii) highlights the construction of a composed index which summarizes the three areas. These findings confirm the role covered by immigrants in labour factor is more than complementarity rather than substitutability. In addition, most of the immigrants are in age for working, and in good health, work, at least in part, regularly and pay taxes, both direct and indirect, increasing the resources in the coffers of the state.
\end{abstract}

Keywords: Immigration, SEM-PLS Path modelling, effects on the labour market, effects on the economy, effects on society.

\section{Introduction}

Italy, for some decades is being populated by people from all over the world and who carry with them not only their skills, their knowledge and abilities, but also their dreams and desires. Dealing with the topic of immigration in Italy is not so simple; prejudices, also increased by the media, are able to influence the opinion of individuals. On several occasions our country seems to have forgotten its past as a country of emigration, pointing the finger at the "new" and massive flows, with the most disparate accusations, often unfounded. We often forget, not only of the economic role of immigrants in our country, carrying out tasks deserted by fellow countrymen or, however, at a cost that benefits our businesses, but also of the fundamental importance that these individuals have as human beings.

The imposing dimension of the migratory phenomenon in Italy, as well as in Europe, is the result of various factors of expulsion from the countries of origin of immigrants, such as political instability in some countries of Asia and Africa, poverty and conflict, and of our country, such as the demand for low-cost labour and democracy. Immigration is, therefore, a complex phenomenon and presents multidisciplinary characters, as varied as there are aspects that characterize the immigration in itself: from the reasons to leave the country of origin, the way of arrival, the treatment in the centres of reception, to repatriation, and so on, and whose treatment is almost never exhaustive. But, through the appropriate analyses, geared to grasp the relevant aspects from the point of view of the objectives, one can reach a broad picture of the phenomenon.

The aim of the work is to provide elements that allow determining the effects of the presence of many immigrants in Italy. The analysis has therefore focused on three areas: the labour market, the economy and social life. In particular, with regard to the labour market, the issue of substitutability/complementarity of foreigners with respect to Italian workers is addressed, as well as the main characteristics of the relationship between education, working conditions and wage of immigrants. In relation to the impacts on the economy, the issues of the public budget, the workforce for businesses, the remittances, public finance issues, the impacts on the gross domestic product are dealt with. As far as social impacts and integration are concerned, the roles of family and housing, deviant behaviours, and economic integration are described. Furthermore, a composed index (immigrants' situation), which summarizes the elements described above (effects on the labour market, effects on the economy, effects on society), is presented in this study. 
The index on immigrants's intuition is constructed using partial least squares structural equation modeling (PLSSEM).

\section{Economic theories on migration}

There are many economic theories that have tried to explain the migration phenomenon. According to Massey (1993), neoclassical economics explains the massive displacements of the population through the wage differences between the countries of origin and those of destination. The studies by Wallerstein (1985) and Sassen (2002) are also based on these assumptions. They subdivide the motivations into factors of expulsion and attraction.

Emigrations, therefore, are based on individual motivations that attempt to maximize individual income. Workers in excess of the demand for work move where there is a satisfactory job demand. They will maximize their income, using their human capital, or themselves.

Another theory is that which refers to the maximization of the general well-being of the immigrant, a welfare that goes beyond income alone (Hugo, 1994). Based on this, what drives them to emigrate is based on employment opportunities present in the destination country, availability of capital, as well as opportunities for survival. The use of remittances, both for consumption and for investments, is included in this case. The neoclassical theory, however, presents the defiance due to the fact that neglects some aspects, or the motivations that go beyond the economic character.

There are some theories that try to remedy the gaps presented by the neoclassical theory. In addition to the mere labour market, other aspects are considered that influence it and therefore create a greater supply of available labour. In some countries, in fact, such as those in the Third World, the labour market may be almost non-existent or inaccessible. According to O. Stark (1985), the unit of analysis is not the individual but he and his family, which face not only the maximization of profits, but the minimization of risks.

Another reason that may lead to immigration, according to R. K. Merton and A. S. Kitt (1950), is based on the concept of relative deprivation that is the inferiority of some individuals compared to others in the field of living conditions in general. According to the theory of the dual labour market, whose proponent is M.J. Piore, migrations are motivated by factors of attraction by developed economies, or by the demand for foreign import labour. However, the flows remain over time. There are some professions that the natives do not intend to do, the more disqualified ones, for social reasons, and that, for a reduction of job offer for these tasks, should lead to an increase in wages. All this would stimulate inflationary increases; immigrants face this problem, because through their employment the salary levels for this type of job are stable.

\section{Immigration in Italy}

Immigration, which began to manifest between the seventies and eighties, is a relatively new event for Italy, which in the course of its history has experienced the opposite phenomenon: emigration. The motivations that push non-European foreigners and European citizens to choose Italy as a destination are not homogeneous. The causes of migration in the last thirty years have been the most disparate and their evaluation has been complex. Using a simplistic classification, in the causes of the new migrations identify the push factors of the countries of exodus, and the pull factors of the landing countries. Expulsion factors include demographic, economic, social and political reasons. From a demographic point of view, immigration is linked to a demographic explosion that has mainly occurred in Third World countries. The increase of the population in underdeveloped countries is due to the reduction in the mortality rate, which remains high compared to the more developed countries. Moreover, in the poor countries the birth rate has always been very high. But this demographic increase alone would not represent an expulsion factor without a worsening of the living conditions of the population: widespread poverty together with environmental degradation, lack of infrastructure, manifestations of aggression and violence. The political factor (dictatorships, civil wars and persecutions) also plays a fundamental role in the migration flow. This should make us reflect on why many migrants risk their lives, often losing them, to escape from the territory in which they live. The Mediterranean has become over the years, a place where some of the greatest tragedies of foreign immigration have occurred: that of North Africans who, illegally transported to overcrowded boats, have lost their lives in one of the most famous and beautiful seas of 'hemisphere. 
As regards the factors that have played a decisive role in the start of new migrations, they are primarily economic. Of these, the main reason concerns the wage differentials between the countries of origin of the emigrants and the host countries: the wage levels of the underdeveloped countries are so low that they would be unthinkable in Italy. Furthermore, the favourable exchange rate of remittances should be considered, which constitutes a further advantage deriving from the provision of work outside the country of belonging.

Another attraction factor, especially in the period preceding financial and economic crisis of the 2007, was the demand for cheap and flexible labour. The lower cost of labour for immigrants stems not only from the immigrants' willingness to accept low salaries (but very high, as we said, compared to the country of origin), but also by the possibility of implementing a tax evasion. If foreign labour is irregular, it is what constitutes the socalled "shadow economy". In addition to these mainly economic motivations, there are others of a psychological, cultural and social nature: the fascination of the West and the desire to reunite with family members.

\section{The current situation in Italy}

The observation of the first migratory flows of our country occurred since the publication of the data of the 1981 census, in which the demographic increase achieved with respect to the previous decade was considerable. In fact, if in the 1961 census foreigners residing in Italy amounted to 62,780, in that of 1981 this number was more than tripled, equal to 210,937. Table 1 gives a quantitative and qualitative idea of the phenomenon. From an initial analysis it can be seen how, from a little over two hundred thousand foreigners residing in Italy, it passed to about 350,000 foreigners in 1991. But the real boom occurs at the beginning of the 21 st century, with the presence of $1,334,889$ foreigners at the 2001 census, and especially in 2017, the growth of immigration takes on unprecedented rates, with over 5,000,000 foreigners. The increase in the number of foreigners reported by Istat was the direct consequence of family reunification, through the arrival of a large number of relatives of foreigners present in Italy, and the regularization of their position through the obtaining of residence permits.

Regarding the ethnic composition of immigrants in Italy it is possible to assert that it is quite varied, including nationalities from all parts of the world: from Eastern Europe, North Africa, Asia, Central and South America.

It seems interesting to know what the main foreign citizens of last year were: the most significant component is made up of the Romanians (1,168,552 units), followed by the Albanians (448,407 units) and Moroccans (420,651 units). In almost all regions, most immigrants come from Romania, with peaks in Basilicata (45\%) and in Lazio and Piedmont (35\%). In Campania, foreigners are mostly Ukrainians (18.5\%), while in Albania there are Albanians (17.0\%).

Table 1: Foreigners residing in Italy in the years 2005-2017 (absolute values)

\begin{tabular}{|c|c|c|c|c|c|c|c|c|c|c|c|c|c|}
\hline Paesi & 2005 & 2006 & 2007 & 2008 & 2009 & 2010 & 2011 & 2012 & 2013 & 2014 & 2015 & 2016 & 2017 \\
\hline Albania & 316659 & 348813 & 375947 & 401949 & 441396 & 466684 & 482627 & 450908 & 464962 & 495709 & 490483 & 467687 & 448407 \\
\hline China & 111712 & 127822 & 144885 & 156519 & 170265 & 188352 & 209934 & 197064 & 223367 & 256846 & 265820 & 271330 & 281972 \\
\hline FormerYugoslavia & 64.070 & 64.411 & 68.542 & $\ldots$ & $\ldots$ & $\ldots$ & $\ldots$ & $\ldots$ & $\ldots$ & $\ldots$ & $\ldots$ & $\ldots$ & $\ldots$ \\
\hline Serbia & & & & & 57826 & 53875 & 52954 & 43022 & 43816 & 46958 & 43811 & 42264 & 39937 \\
\hline Montenegro & & & & & 4243 & 4002 & 4588 & 2337 & 2939 & 3215 & 2731 & 2721 & 2298 \\
\hline Philippines & 82625 & 89668 & 101337 & 105675 & 113686 & 123584 & 134154 & 129188 & 139835 & 162655 & 168238 & 165900 & 166459 \\
\hline France & 26951 & 28021 & 29205 & 30803 & 32079 & 32956 & 33400 & 23985 & 25016 & 29078 & 27696 & 28634 & 29281 \\
\hline Germany & 35559 & 36834 & 38135 & 40163 & 41476 & 42302 & 42531 & 34936 & 35576 & 38136 & 36749 & 36661 & 36660 \\
\hline India & 54288 & 61847 & 69504 & 77432 & 91855 & 105863 & 121036 & 118409 & 128903 & 142453 & 147815 & 150456 & 151430 \\
\hline Morocco & 294945 & 319537 & 343228 & 365908 & 403592 & 431529 & 452424 & 408667 & 426791 & 454773 & 449058 & 437485 & 420651 \\
\hline moldova & 37971 & 47632 & 55803 & 68591 & 89424 & 105600 & 130948 & 132175 & 139734 & 149434 & 147388 & 142266 & 135661 \\
\hline Poland & 50794 & 60823 & 72457 & 90218 & 99389 & 105608 & 109018 & 84749 & 88839 & 97566 & 98694 & 97986 & 97062 \\
\hline UK & 22318 & 23324 & 24673 & 26448 & 28174 & 29184 & 29560 & 22839 & 23744 & 26377 & 25864 & 26634 & 27208 \\
\hline Romania & 248849 & 297570 & 342200 & 625278 & 796477 & 887763 & 968576 & 834465 & 933354 & 1081400 & 1131839 & 1151395 & 1168552 \\
\hline Senegal & 53941 & 57101 & 59857 & 62620 & 67510 & 72618 & 80989 & 73702 & 80325 & 90863 & 94030 & 98176 & 101207 \\
\hline tunisia & 78230 & 83564 & 88932 & 93601 & 100112 & 103678 & 106291 & 82997 & 88291 & 97317 & 96012 & 95645 & 94064 \\
\hline Ukraine & 93441 & 107118 & 120070 & 132718 & 153998 & 174129 & 200730 & 180121 & 191725 & 219050 & 226060 & 230728 & 234354 \\
\hline USA & 14155 & 14433 & 14904 & 15036 & 15324 & 15708 & 15620 & 12184 & 13165 & 14963 & 14303 & 14512 & 14649 \\
\hline Peru & 53378 & 59269 & 66506 & 70755 & 77629 & 87747 & 98603 & 93841 & 99173 & 109851 & 109668 & 103714 & 99110 \\
\hline
\end{tabular}

\section{Source: ISTAT}

\section{The economic and social impacts of immigration in Italy}

The economic impacts of immigration have long been debated and studied by both economists and sociologists, but they have often been influenced by positions of public antagonism against this phenomenon. To highlight the effects of the entry of foreign population into Italy, three macro-areas have been observed in this work: the labour market, public finance issues and the social life of immigrants. 


\subsection{The effects on the labour market}

As mentioned previously, economic motivation plays a particular role in the attraction of immigration. The wealth gaps between the migrants' countries of origin and the greater chances of achieving their individual aspirations have fuelled migratory flows to Italy. Like the other advanced recipients of immigrants, in Italy most of the latter tend to find employment in those activities rejected by the natives. The most significant part of immigrants, in fact, works purely in the de-skilled sectors.

As mentioned previously, economic motivation plays a particular role in the attraction of immigration. The wealth gaps between the migrants' countries of origin and the greater chances of achieving their individual aspirations have fuelled migratory flows In Italy most immigrants find work purely in the de-skilled sectors going to carry out those activities rejected by the natives.

In the South, a large proportion of immigrants find employment in agriculture, while in the northern regions, they are turning to industry; the itinerant trade is instead present throughout Italy. The most widespread activities among immigrants, today as in the past, are those related to domestic service, in the hotel and restaurant sector, porterage, night-watch, work in cleaning companies, the trade in exotic crafts or counterfeit goods or smuggling, and in construction. There are also intellectual employments: editorial collaborations, translations, private language lessons. This type of work, although more qualified, has not accompanied an adequate remuneration, indeed, is often underpaid and precarious.

Foreigners are also employed in domestic work and this is due not only to the relative reluctance of Italian women to carry out these activities, especially in the most servile forms, but also to an inadequate welfare system in a context of greater independence and female employment. The domestic work and assistance of the elderly has often been culturally devalued by society, when it would have been necessary, instead, to recognize its high social usefulness. Moreover, the situations in which the tasks performed implied para-nursing performances, as opposed to the trivialization of such activities as servile, were not infrequent. From the short list of the main employments of immigrants it is clear that there is no substitutability between foreign and native workers, and therefore there are no labour thefts of immigrants, since they occupy jobs defected by the Italian labour force. There is, therefore, a complementarity between foreign workers and Italians, with minimal effects on wages and employment.

\subsection{The effects on the economy}

In Italy, in recent decades, we are witnessing more and more the phenomenon known as the aging of the population. The first beneficial contribution of foreign immigration to our country has taken place precisely in the demographic, mitigating the imbalances of the aging population, through the younger age of immigrants and the greater fruitfulness of the same. Thanks to the new arrivals and their births they gave a demographic contribution. A huge boost has been given to the workforce since the immigrants of working age (15 - 64 years) represent the majority: in 2015 there were almost 4 million, $10.0 \%$ of the total workforce.

A negative economic impact of immigration has been to allocate part of the income to remittances, in fact foreign workers, especially those originating from poor countries, are encouraged to save money, sending the sums of these savings to families in order to support them. According to World Bank estimates, the amount of remittances exceeds the total of public development aid and is second only to direct investments abroad. Remittances from our country have experienced a steady growth, like that of incoming migratory flows. It is estimated that $15 \%$ of foreigners' income is allocated to remittances; according to the research carried out by the Institute for the Study of Multiethnicity, in 2015 the immigrants residing in Lombardy were the ones who sent the most money to the families in the countries of origin. But despite the fact that immigration has been a phenomenon that has not held back, the remittances have experienced a decline since 2011, continued in the years to follow.

In particular, from the data provided by the Bank of Italy, from 2005 to 2011, it went from 3.9 billion euros to 7.4 billion euros. It also emerged that in the last decade the country of greatest remittance of remittances was China, surpassed for the first time in 2014 by Romania. This is certainly due to the high number of immigrants coming from this last country.

However, it is estimated that from the formal channels, ie banks and money transfer companies, only part of the monetary flows sent to the countries of origin of the immigrants' transit: one part transits in the suitcase. In our country banks and money transfer companies are very active in the field of remittances, especially the latter, with the creation of ad hoc and more flexible products. In any case, the income received by immigrants, net of outgoing remittances, favoured the Italian economy, fuelling consumption, investment and, consequently, public 
revenues, above all through indirect taxation. Another very important question is therefore whether immigrants for Italy are a cost or an advantage? The net flows for public finances are given by the difference between what is paid into public funds and what is received from the public sector. Studies on the net effect of immigration on public accounts have been multiple and all have pointed out that immigration has a positive impact on public finances. The studies of Romanelli, Rizza and Sartor have found that, in 2009, the revenue on immigrants was equal to 24.9 billion ( $4.5 \%$ of the total), while public spending amounted to 12.6 billion (the $2.7 \%$ ), with a positive net effect of around 12 billion euros. There are many authors who converge on these results.

Foreign immigrants produce less income and have fewer resources to invest, but this does not mean that they are unable to contribute to the Gross Domestic Product. Mass media often tend to emphasize the poverty conditions of immigrants or the relevance of remittances, underestimating their ability to produce GDP. In reality, the situation is not so bad. In 2012, foreign taxpayers were 3.5 million, which reported revenues of 44.7 billion euros (5.6\% of the total). Every immigrant tax payer has obtained an average salary of 12,930 euros per year, with about 7,500 euros less than an Italian worker.

Between 2008 and 2012 foreign taxpayers increased by $9.1 \%$ and their declared incomes increased by 4.3 billion euros, but the economic crisis has eroded real purchasing power and has widened the pay gaps between immigrants. and native residents.

According to the studies of the Leone Moressa Foundation, the Gross Domestic Product created in 2014 by foreign workers is equal to $8.8 \%$ of the national one, amounting to an amount equal to 123 billion euro. This amount is generated by the 2,400,000 foreign workers who work in Italy, representing $10.8 \%$ of total workers. Despite the crisis and the worsening of their employment situation, much more than that of the Italians, their contribution to the Italian GDP remains high.

\subsection{The effects on society}

The social sphere is the area that most represents the condition of immigrants in a country. Integration must be understood as a process of progressive inclusion of immigrants in the society of the host country. It is a multidimensional process, which can be seen from many points of view:

- structural integration, which concerns the relationship between immigrants and specific institutions, such as the labour market, the education system;

- cultural integration, which concerns the learning of useful elements, such as language;

- identification integration, which refers to the adherence to shared values in the welcoming society;

- relational integration, ie the full creation of informal social relations with the population of the host country.

Immigrant families and reunification processes encourage integration between immigrants and the host society, creating a multi-ethnic society, where people of different origins share the same urban spaces, reducing social distances.

Family life favours rooting on the territory and stability. The presence of children plays a positive role in increasing relationships with the outside, both with the school and with extracurricular activities. The increase in school attendance stems from the advent of new generations, children of immigrants who arrived in Italy in past decades. The school represents, after work, the second point of contact between human beings of different ethnic groups, and that is where the game of integration is played and the future of cohabitation is built. The presence of family members is a sign of stabilization of flows, as immigrants can move from a phase of "guests" to residents.

Having a home is an important factor for integration, but immigrants' homes often deviate from the minimum requirements considered acceptable. Immigrants in Italy often live in conditions of overcrowding, exposing a clear housing discomfort. The type of housing, in fact, depends to a large extent on the employment situation, the amount of wages, and the stability of employment. Often the housing factor is considered marginal, but in reality, it is relevant in the process of integration of immigrants, since it influences different aspects. The most immediate link between accommodation and integration concerns the importance of residence in obtaining a residence permit for work, with the possibility of improving one's own legal position, as well as procedures for family reunification that require the immigrant to have a adequate accommodation also for his family. Another factor, this time negative, that influences integration is that related to deviant behaviour, a very sensitive issue that the Italian population shows a certain sensitivity. There is a tendency towards the growth of foreigners among the reported and those arrested or condemned, and this causes greater discomfort of immigrants than Italians. 
From this derives the risk that negative reactions to all immigrants arise from the Italian society, making the process of integration of immigrants more difficult. Regarding civil society, many associations have arisen in favour of foreign integration, cultural, welfare and information. Associationism helps support for immigrants, especially in the early stages of migration, and fosters intercultural dialogue between all ethnic groups, including the indigenous peoples. Despite this, continue to persist in our country, a share of Italians who consider immigrants a danger to their identity, for public order and security. Hateful forms of discrimination that, starting from xenophobia, can come to racist exclusions, often based on ignorance, confirmed by the spread of ethnic stereotypes.

\section{Index - Immigrants'situation (IIS)}

The purpose of this work is precisely to propose an index, which is able to include all the information previously described, allowing an immediate reading of what is the current situation of an immigrant.

\subsection{Methodological research}

The proposed index was created using partial least squares structural equation modeling (PLS-SEM), it is a method of structural equation modeling which allows estimating complex cause-effect relationship models with latent variables. The latent variables are variables that are not directly observed but are rather inferred (through a mathematical model) from other variables that are observed (directly measured).

The PLS structural equation model is composed of two sub-models:

- the measurement model, that represents the relationships between the observed data and the latent variables;

- the structural model, that represents the relationships between the latent variables.

\subsection{Discussion and results}

In the table 2, the latent variables are reported, each necessary to describe one of the three areas described above and the manifest variables (sources: ISTAT and Bank of Italy) from which they derive.

Table 2: Latent and manifest variables

\begin{tabular}{|l|l|}
\hline Latentvariables & Manifestvariables \\
\hline \multirow{4}{*}{ The effects on the labour market $(E L)$} & Employment rate indeterminate time $\left(\lambda_{1}\right)$ \\
\cline { 2 - 2 } & Unemployment rate $\left(\lambda_{2}\right)$ \\
\cline { 2 - 2 } & Youth unemployment rate $\left(\lambda_{3}\right)$ \\
\cline { 2 - 2 } The effects on the economy $(\mathrm{EE})$ & Part time Job Rate $\left(\lambda_{4}\right)$ \\
\cline { 2 - 2 } & Employment rate determinate time $\left(\lambda_{5}\right)$ \\
\cline { 2 - 2 } The effects on society $(E S)$ & $\%$ outgoing money $\left(\beta_{2}\right)$ \\
\cline { 2 - 2 } & $\%$ net streams $\left(\beta_{3}\right)$ \\
\hline & $\%$ structural integration $\left(\gamma_{1}\right)$ \\
\cline { 2 - 2 } & $\%$ cultural integration $\left(\gamma_{2}\right)$ \\
\cline { 2 - 2 } & $\%$ identification integration $\left(\gamma_{3}\right)$ \\
\cline { 2 - 2 } & $\%$ relational integration $\left(\gamma_{4}\right)$ \\
\hline
\end{tabular}

The choice of the observed variables was made taking into account not only the considerations produced previously but also considering that each latent variable obtained must explain a single area, respecting the constraint of one-dimensional. This constraint was verified by Cronbach's Alpha index (values above 0.80 indicate that the test is satisfactory).

Table 3: Cronbach's Alpha index

\begin{tabular}{|l|l|l|}
\hline Latentvariables & Dimensions & Cronbach's Alpha \\
\hline $\boldsymbol{E L}$ & 5 & 0,886 \\
\hline EE & 3 & 0,867 \\
\hline $\boldsymbol{E S}$ & 4 & 0,875 \\
\hline
\end{tabular}

The model used for the determination of the index on the effects of immigration is therefore the following: 


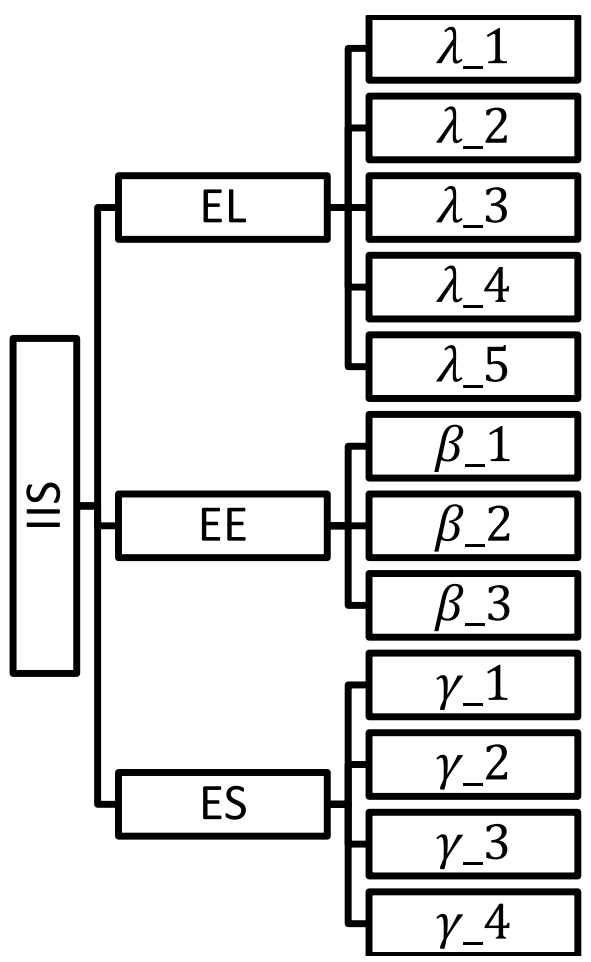

Figure 1: Used model

The observed variables, used in model, have to be normalized and subsequently corrected. Data correction is necessary because the model is only applicable to positive values. Ordinary Least Squares regression is applied for each latent variable and the respective manifest variables, obtaining the estimates of the outer weights.

Table 4: outer weights

\begin{tabular}{|l|c|l|}
\hline Latentvariables & Manifestvariables & Outerweights $\left(\boldsymbol{\omega}_{i}\right)$ \\
\hline \multirow{4}{*}{$E L$} & $\lambda_{1}$ & $\mathbf{0 , 0 0 8}$ \\
\cline { 2 - 3 } & $\lambda_{2}$ & $\mathbf{0 , 0 0 8}$ \\
\cline { 2 - 3 } & $\lambda_{3}$ & $\mathbf{0 , 0 0 7}$ \\
\cline { 2 - 3 } & $\lambda_{4}$ & $\mathbf{0 , 0 1 1}$ \\
\cline { 2 - 3 } & $\lambda_{5}$ & $\mathbf{0 , 0 1 0}$ \\
\hline \multirow{4}{*}{$E S$} & $\boldsymbol{\beta}_{1}$ & $\mathbf{0 , 0 1 2}$ \\
\cline { 2 - 3 } & $\boldsymbol{\beta}_{2}$ & $\mathbf{0 , 0 0 7}$ \\
\cline { 2 - 3 } & $\boldsymbol{\beta}_{3}$ & $\mathbf{0 , 0 0 8}$ \\
\cline { 2 - 3 } & $\boldsymbol{\gamma}_{1}$ & $\mathbf{0 , 0 0 9}$ \\
\cline { 2 - 3 } & $\gamma_{2}$ & $\mathbf{0 , 0 1 0}$ \\
\cline { 2 - 3 } & $\gamma_{3}$ & $\mathbf{0 , 0 0 9}$ \\
\cline { 2 - 3 } & $\gamma_{4}$ & $\mathbf{0 , 0 1 1}$ \\
\hline
\end{tabular}

These estimates make it possible to know the contribution that each observed variable has in the construction of the latent variables. In the latent variable EL, the manifest variables that have a greater weight are "Part time Job Rate" and "Employment rate determinate time". This is mainly due to the fact that immigrants find work in all those areas where there is a strong incidence of seasonal work (agriculture, catering, construction).

In the latent variable $\mathrm{EE}$ has a greater weight the variable "\% workforce", instead the lower weight is given by variable "\% outgoing money". This highlights two key factors:

- The income of immigrants, despite the remittances, has favoured the Italian economy, feeding consumption and investment

- The remittances in recent years are having a decline and this means that in Italy have moved entire families.

In the latent variable ES, the manifest variables that have a greater weight are "\% cultural integration" and 
“\% relational integration”. Latent Variables are obtained as a linear combination of the observed variables:

$$
E L=\sum_{i=1}^{5} \omega_{i} * \lambda_{i} \quad E E=\sum_{i=1}^{3} \omega_{i} * \beta_{i} \quad E S=\sum_{i=1}^{4} \omega_{i} * \gamma_{i}
$$

The parameters of the structural model thus obtained are:

Table 5: parameters of the structural model

\begin{tabular}{|l|l|l|l|}
\hline & Correlation & Path coefficient & Contribution to $\mathrm{R}^{2}$ \\
\hline EL & 0,952 & 0,432 & 44,126 \\
\hline EE & 0,711 & 0,268 & 13,637 \\
\hline ES & 0,892 & 0,415 & 42,237 \\
\hline
\end{tabular}

The correlation values show how the major influence on the index is given by the variable EL. A high correlation is also given by the variable ES and this implies how the social sphere and therefore the full integration is a fundamental element on which to act to improve the consideration that Italians have of immigrants. The path coefficients express the degree of dependence of each latent variable exogenous from the endogenous ones and allow the identification of the complex index:

$$
I I S=(0,432 * E L)+(0,415 * E S)+(0,268 * E E) .
$$

\section{Conclusions}

First of all, we have been able to understand the evolution of the migratory phenomenon: it is a recent phenomenon, but its scope has been vast (five million foreigners, in 2017, on a population of sixty million is not a negligible figure). With this work we wanted to highlight the phenomenon of immigration in Italy. The results have shown that immigration has experienced surprising growth over the last decade: from one million immigrants in 2002, it has increased to more than five million in 2017.

The reasons for arrival are always greater and the flows are increasingly impressive. If in the early years of 2000, the main motive was the economic one, after the economic crisis it has been seen that the motivations must be found in the family factor and in the reasons related to political asylum. The latter, in particular, depend on the political instability present in the countries to which the immigrants belong. Family reunification is a strong attraction for immigrants and is the starting point for integration. Reunification can increase the stability of immigrants and promote social integration.

As for the general impacts, we have seen how they deny any kind of accusation exposed by a slice of public opinion. First of all, it is the labour factor: the role covered by immigrants has been more than complementarity rather than substitutability; or better. This last factor has been assumed for that part of very disqualified tasks, and therefore represent a minority group of the range of functions that can be explained in our country. The problems, therefore, linked to the theft of work to the detriment of Italians do not exist. There are also no problems related to an erosion of public resources; on the contrary, most of the immigrants are of working age, with an education acquired in the country of origin, and in good health. They work, at least in part, regularly and pay taxes, both direct and indirect, increasing the resources in the coffers of the state. On the contrary, it is the Italians who make the most use of health services, assistance and pensions. This is due to the aging of the Italian population, leading to a decrease in workers of working age but to a greater use of public spending. But the positive outcomes of immigration do not end here. They contribute to the formation of the GDP of our country. A further feature of migrant workers is their over-education with respect to the work done.

Economic participation is influenced by factors related to personal characteristics, such as language proficiency, but discriminating factors are often present. This represents an inefficiency of our economic system. These workers would represent an opportunity, which is not exploited, in order to generate greater competitive advantages of Italy towards Europe.

Alongside low-skilled jobs, there is the problem of exploitation and low pay of foreign workers, which implies that they can't overcome their poverty. For the immigrants a respectable job would guarantee a social redemption and from poverty, like all human beings. The reality is that society and the Italian economy are supported by the contribution of these subjects who have filled up vacuums that we ourselves have not been able to correct, such as the demographic decline. Immigrants are an opportunity that should not be rejected. They are a resource, and 
Italian citizens understand it, but perhaps they are afraid of being overcome socially or economically, and it is perhaps for this reason that they do not want to fully recognize the skills and qualities of foreigners.

\section{Bibliography}

Abbondante F., Prisco S.(2009). La condizione giuridica degli immigrati e le politiche degli enti territoriali tra integrazione e rifiuto, Stabilità dell’Esecutivo e democrazia rappresentativa, Scudiero M., Jovene.

Ambrosini M., AbbatecolaE.(2009), Migrazioni e società, Franco Angeli publication.

Ambrosini M.(2009), Ai confini della cittadinanza. Processi migratori e percorsi di integrazione in Toscana, Politiche migratorie, Franco Angeli publication.

Ambrosini M., BonizzoniP.(2011), I nuovi vicini - Famiglie migranti e integrazione sul territorio, Fondazione Ismu Iniziative e Studi sulla Multietnicità.

Bade K. J. (2001). L'Europa in movimento. Le migrazioni dal Settecento a oggi, Laterza publication.

Bansak K., Hainmueller J., HangartnerD.(2016). How economic, humanitarian, and religious concerns shape European attitudes toward asylum seekers, Science. 2016 Oct 14;354(6309):217-222. Epub 2016 Sep 22.

BarbangeloA.(2012), Le rimesse dei migranti, East- EuropeanGeopolitics Magazine.

BriguglioS.(2013). Pubblico impiego: accesso vietato agli stranieri, www.lavoce.info, 2013.

Confindustria Centro Studi (2016), Immigrati: da emergenza ad opportunità, Scenari Economici, Parte Speciale.

Contarello A., Marini I., Nencini A., Ricci G.(2011).Rappresentazioni sociali dell'invecchiamento tra psicologia e letteratura, Psicologia \&Sociedade, 23(1), 171,180.

Conti C., Gabrielli D., Prati S., Strozza S.(2011).Misurare l'immigrazione e la presenza straniera: una sfida continua per la statistica ufficiale, Dossier Istat.

De Arcangelis G., Di Porto E., Santoni G.(2015).Le conseguenze dell'immigrazione, www.lavoce.info.

Dumont J. C.(2014).Is migration good for the economy?, Migration Policy Debates, OECD Publishing, 2014.

Fondazione Leone Moressa(2015).Il Valore dell'immigrazione, Il Mulino publication.

Fondazione Leone Moressa(2013).Le rimesse in Italia nel 2013, Il Mulino publication.

GrisantiC.(2016).I profughi non sono tutti uguali, http://www.internazionale.it/ 2016.

Global Migration Group (GMG) (2012). Comunicazione sui diritti umani dei migranti in situazione irregolare, 30 settembre 2010,L'immigrazione e la normativa internazionale dei diritti umani, Guida per operatori del diritto n. 6, International Commission of Jurists.

Guadagno E.(2012), Politiche migratorie e law and economics: una critica all'approccio mainstream, Ianus n.6.

Istat(2015), L'integrazione degli stranieri e dei naturalizzati nel mercato del lavoro, http://www..istat.it.

Istat(2017), Rapporto annuale 2017, http://www..istat.it.

Istat(2017), Statistiche e Report, Indicatori Demografici 2017, http://www..istat.it

Istat(2017), Statistiche e report, Natalità e fecondità nella popolazione residente 2016, http://www..istat.it

Melotti U.(1992), L'immigrazione una sfida per l'Europa, Edizioni Associate. Collana: Nord-Sud.

Organizzazione Mondiale delle Migrazioni(2016), Study on Migrants' Profiles, Drivers of Migration, and Migratory Trends.

Papavero G.(2016), Le rimesse degli immigrati, 2015, Fondazione Ismu - Iniziative e Studi sulla Multietnicità.

Pastore F., Salis E., VillosioC.(2015), L'Italia e l'immigrazione low cost, fine di un ciclo?, Fieri Working Papers.

Regolamento CE 862/2007, sulle statistiche comunitarie in materia di migrazione e di protezione internazionale, http://eur-lex.europa.eu/

ReyneriE.(1998), Immigrazione ed economia sommersa, Studi Emigrazione.

Rizza P., Romanelli M., SartorN.(2013).Immigrati e italiani: le disuguaglianze nel dare e nell'avere tra welfare e fiscalità, Le disuguaglianze nei diritti e nelle condizioni di vita degli immigrati, Il Mulino publication.

Tarantola A. M.(2006).Economia solidale e sviluppo sostenibile nell'era della post globalizzazione, Bankof Italy publication.

Venturini A., Vignoli D.(2015). Donne immigrate, come lavorano e come si sposano, http.//www.lavoce.info.

ZanfriniL.(2007), Sociologia delle migrazioni, Laterza.

Monecke A., LeischF.(2012). semPLS: Structural Equation Modeling Using Partial Least Square, Journal of Statistical Software, 48(3).

Tenenhaus M., Vinzi V., Chatelin Y., Lauro C.(2005). PLS path modeling. Computational Statisitics and Data analysis, 48(1), pp 159-205.

Sabry M. Abd-El-Fattah, Hessa Abdulrahman Fakhroo (2012). The Relationship among Paternal Psychological Control and Adolescents' Perfectionism and Self-Esteem: A Partial Least Squares Path Analysis, Psychology, 3(5).

Joseph F. Hair, Jr., G. Tomas M. Hult, Christian Ringle, Marko Sarstedt (2016), A Primer on Partial Least Squares Structural Equation Modeling (PLS-SEM), Sage publication. 